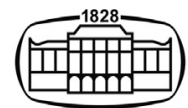

AKADÉMIAI KIADÓ

\section{Acta Veterinaria Hungarica}

$68(2020) 4,380-386$

DOI:

$10.1556 / 004.2020 .00052$

(c) 2021 The Author(s)

\section{ORIGINAL RESEARCH} PAPER

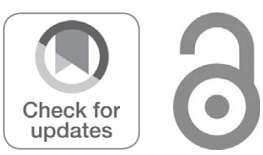

\title{
The impact of quercetin on a porcine intestinal epithelial cell line exposed to deoxynivalenol
}

\author{
JUDIT MERCÉDESZ POMOTHY* $\odot$, KATRINA GATT, \\ ÁKOS JERZSELE and ERZSÉBET PÁSZTI GERE
}

Department of Pharmacology and Toxicology, University of Veterinary Medicine Budapest, István u. 2, H-1078 Budapest, Hungary

Received: June 2, 2020 • Accepted: August 20, 2020

Published online: February 24, 2021

\begin{abstract}
Quercetin (Que) is present in many vegetables and fruits as a secondary antioxidant metabolite. Deoxynivalenol (DON) produced by various Fusarium mould species can induce cytotoxicity and oxidative stress in the gastrointestinal tracts of humans and farm animals. The aim of this study was to investigate the effects of Que on DON-induced oxidative stress in a non-tumourigenic porcine IPEC-J2 cell line. Two experimental designs were used in our experiments as follows: (a) pretreatment with 20 $\mu \mathrm{mol} / \mathrm{L}$ Que for $24 \mathrm{~h}$ followed by 1-h $1 \mu \mathrm{mol} / \mathrm{L}$ DON treatment and (b) simultaneous application of 20 $\mu \mathrm{mol} / \mathrm{L}$ Que and $1 \mu \mathrm{mol} / \mathrm{L}$ DON for $1 \mathrm{~h}$. Cell cytotoxicity, transepithelial electrical resistance (TER) of cell monolayers and extracellular/intracellular redox status were studied. It was found that DON significantly decreased TER and triggered oxidative stress, while Que pretreatments were beneficial in maintaining the integrity of the monolayers and alleviated oxidative stress. However, co-treatment with Que was unable to preserve the integrity and redox balance of the cells exposed to DON. These results indicate that only the 24 -h preincubation of cells with $20 \mu \mathrm{mol} / \mathrm{L}$ Que was beneficial in compensating for the disruption caused by DON in extracellular oxidative status.
\end{abstract}

\section{KEYWORDS}

quercetin, deoxynivalenol, IPEC-J2, transepithelial electrical resistance, oxidative stress

\section{INTRODUCTION}

Recently, the number of studies on the beneficial effects of plant-based dietary polyphenols has been growing continuously. Flavonoids can be further divided into six subclasses, namely flavonols, flavones, isoflavones, flavanones, anthocyanins and flavanols (Kroon et al., 2004; Kumar and Pandey, 2013). Flavonoids are known to have antibacterial (Xie et al., 2015), anticancer (Chahar et al., 2011; Abotaleb et al., 2018), anti-inflammatory (Serafini et al., 2010), and antioxidant properties (Galleano et al., 2010; Brunetti et al., 2013). Quercetin (Que) is a well-studied plant derived flavonol (D'Andrea, 2015) (Fig. 1). Vergauwen et al. (2016) reported that Que was beneficial in a concentration range of $25-800 \mu \mathrm{mol} / \mathrm{L}$ to reduce the levels of intracellular reactive oxygen species (ROSs) and strengthen the integrity of the monolayer of porcine non-tumourigenic IPEC-J2 cells. As indicated by Chen et al. (2018), Que protects IPEC-J2 cells from oxidation-induced apoptosis in $16.5 \mu \mathrm{mol} / \mathrm{L}$ concentration for $3 \mathrm{~h}$.

It is extremely challenging to provide mycotoxin-free feedstuffs for livestock. Pigs are very sensitive to mycotoxin-contaminated feeds (Diekman and Green, 1992). In the temperate climate zone, Fusarium mould species occur frequently and are responsible for producing a wide variety of trichothecene mycotoxins such as deoxynivalenol (DON) (Placinta et al., 1999; Sundheim et al., 2013) (Fig. 1). In farm animals, dietary exposure to DON decreases growth performance. An important function of gastrointestinal epithelia is to provide a barrier against the penetration of food contaminants and pathogens present in the intestinal 


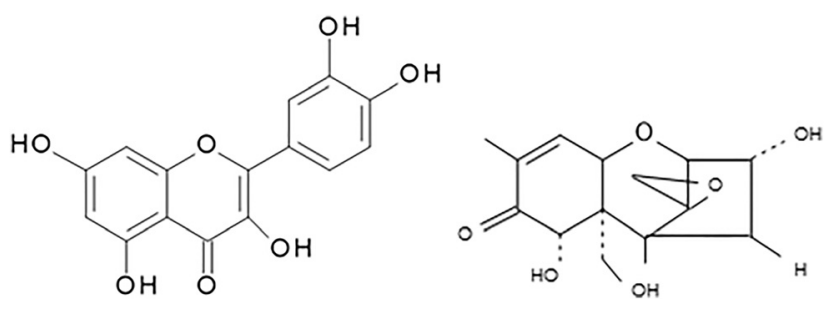

Fig. 1. The chemical structures of quercetin (Que) and deoxynivalenol (DON)

lumen. The disruption of the intestinal barrier allows increased penetration of normally excluded intraluminal substances that may promote intestinal disorders.

In general, DON interferes with the normal functions of the mitochondria as it generates ROS, which can lead to apoptosis. Oxidative stress is a phenomenon which occurs in a cell when the concentration of ROS exceeds the antioxidant capacity. ROS can initiate the process of lipid peroxidation causing damage to phospholipids and lipoproteins of the cell membrane and damage to DNA by propagating a chain reaction (AbdulSalam et al., 2016; Su et al., 2019). Moreover, oxidative stress may increase cell apoptosis (Chen et al., 2018). It is proven that the toxicity of trichothecene mycotoxins is mainly based on oxidative stress. Wan et al. (2019) studied oxidative stress in the human cancerous HT29 cell line and it was found that $1 \mu \mathrm{mol} / \mathrm{L}$ DON significantly elevated the intracellular ROS after an incubation time of $6 \mathrm{~h}$. The antioxidant properties of Que were previously proved in in vitro and in situ experiments. It is suggested that Que might scavenge ROS in two ways. One mechanism can be that Que directly acts on both intracellular and superoxide anion radicals or other free radicals and eliminates them. The other possible mode of action of Que seems to involve initiation of antioxidant pathways of cells via promoting the production of antioxidant enzymes (Ružić et al., 2010; Sak, 2014). Trichothecene mycotoxins inhibit protein synthesis in eukaryotic cells (Holladay et al., 1993), especially, as Pinton et al. (2009) and Li et al. (2011) have reported, in epithelial and immune cells, where the rates of cell replications are high.

Porcine intestinal epithelial IPEC-J2 cells are nontumourigenic, intestinal columnar epithelial cells, which were isolated from the mid-jejunum of neonatal piglets. The IPEC-J2 cell line closely mimics in vivo conditions, which makes it a good model system (Zakrzewski et al., 2013) for studies on oxidative stress. It has been previously shown that $\mathrm{H}_{2} \mathrm{O}_{2}$ administration can lead to a weakened monolayer function in IPEC-J2 cells (Paszti-Gere et al., 2012a,b).

Vergauwen et al. (2016) conducted experiments with Que-treated IPEC-J2 cells, in which Que was effective against $\mathrm{H}_{2} \mathrm{O}_{2}$-induced oxidative stress and helped to strengthen the barrier functions. According to Goossens et al. (2012), DON caused a decreased in transepithelial electrical resistance (TER) and, at the same time, enhanced the permeability of the IPEC-J2 cell monolayers.

The goal of this study was to evaluate the effects of Que on IPEC-J2 cell line exposed to non-cytotoxic concentrations of DON. This study was focused on monitoring the
TER values and determining the changes in extracellular $\mathrm{H}_{2} \mathrm{O}_{2}$ levels and intracellular ROS production in IPEC-J2 cells after Que and DON treatments.

\section{MATERIALS AND METHODS}

\section{Cell line and culture conditions}

IPEC-J2 cells were maintained in a complete culture medium made of a 1:1 mixture of Dulbecco's modified Eagle medium and Ham's F-12 nutrient medium (DMEM:F12, Merck, Darmstadt, Germany), 5\% foetal bovine serum, $5 \mu \mathrm{g} /$ $\mathrm{mL}$ insulin, $5 \mu \mathrm{g} / \mathrm{mL}$ transferrin, $5 \mathrm{ng} / \mathrm{mL}$ selenium, $5 \mathrm{ng} / \mathrm{mL}$ epidermal growth factor and $1 \%$ penicillin-streptomycin solution. All substances were purchased from Thermo Fisher Scientific (Waltham, MA, USA). To remove the cells from the surface, $3 \mathrm{~mL}$ of trypsin-EDTA $(0.05 \%$ trypsin, 0.6 $\mathrm{mmol} / \mathrm{L}$ EDTA) were added to them for $10 \mathrm{~min}$. IPEC-J2 cells forms polarised monolayers after seeded on $75-\mathrm{cm}^{2}$ cell culture flasks with filtered caps (Orange Scientific, Brainel'Alleud, Belgium). The cells were cultured at $37{ }^{\circ} \mathrm{C}$ in a humidified atmosphere of $5 \%$ and the complete culture medium was changed every two days. Cells were used between passages 38 and 42 .

\section{Reagents}

DON and Que were purchased from Merck (Darmstadt, Germany). These compounds were diluted in dimethyl sulphoxide (DMSO) and acetonitrile, which were obtained from Thermo Fisher Scientific (Waltham, MA, USA). The final concentration of acetonitrile or DMSO in the cell culture medium was less than $0.5 \%(\mathrm{v} / \mathrm{v})$. Dissolved substances were sterile filtered with syringe filters (Millex-GV, pore size: $0.2 \mu \mathrm{m}$, Merck, Darmstadt, Germany) before application on the IPEC-J2 cells.

\section{Assessment of the viability of IPEC-J2 cells}

Viability of differentiated IPEC-J2 cells was studied after an incubation time of $24 \mathrm{~h}$ with DON and Que by Neutral Red (NR) uptake assay (Merck, Darmstadt, Germany) (Repetto et al., 2008). The assay was used to evaluate the extent of uptaking the eurhodin dye, which is a well-established indicator for the amount of living cells.

The control cells were incubated with serum-free phenol red-free DMEM:F12 medium (Merck, Darmstadt, Germany). After the incubation time, the media were removed 
and then the cells were washed with phosphate-buffered saline (PBS). A $45 \mathrm{mg} / \mathrm{L}$ NR solution was added to the IPECJ2 cells in serum-free phenol red-free DMEM: F12 medium for $2 \mathrm{~h}$. After this time period, the cells were washed with PBS, and a destaining solution (ethanol/demineralised water/glacial acetic acid, 7.5/7.4/0.15 v/v/v) was applied for 10 min. The viability of the IPEC-J2 cells was measured at 540 nm using an ELISA Plate Reader (EZ Read Biochrom 400, Cambridge, UK).

\section{Experimental layout}

For testing cell viability, the IPEC-J2 cells were seeded onto 6-well culture plates (Sigma, Merck, Darmstadt, Germany) at a density of $1 \times 10^{6}$ cells/well. Each concentration was tested with 5 parallel wells in the case of DON and 8 parallels with Que. For further experiments, the cells were seeded into a 6 -well plate containing 6 membrane inserts (polyester membrane, cell growth area: $4.67 \mathrm{~cm}^{2}$, pore size: $0.4 \mu \mathrm{m}$, Corning Costar Transwell ${ }^{\circledR}$, Merck, Darmstadt, Germany) at a density of $1 \times 10^{6}$ cells/well. IPEC-J2 cells started to differentiate after 8 days; the status of polarisation was checked by TER measurement at each change of medium. TER determinations were carried out using 6 parallel measurements in the case of each concentration. For the measurement of the redox state of the IPEC-J2 cells, 8 parallel examinations were carried out.

Two experimental designs were used to test the combination of the two compounds: (1) Pretreatment with 20 $\mu \mathrm{mol} / \mathrm{L}$ Que for $24 \mathrm{~h}$ followed by the addition of $1 \mu \mathrm{mol} / \mathrm{L}$ DON for $1 \mathrm{~h}(24-\mathrm{h} 20 \mu \mathrm{mol} / \mathrm{L}$ Que + 1-h $1 \mu \mathrm{mol} / \mathrm{L} \mathrm{DON})$; (2) Co-treatment with $20 \mu \mathrm{mol} / \mathrm{L}$ Que and $1 \mu \mathrm{mol} / \mathrm{L} \mathrm{DON}$ for $1 \mathrm{~h}(1-\mathrm{h} 20 \mu \mathrm{mol} / \mathrm{L}$ Que $+1 \mu \mathrm{mol} / \mathrm{L} \mathrm{DON})$. Prior to the treatment, control medium was given to the IPEC-J2 cells.

\section{Evaluation of transepithelial integrity after DON and Que treatments}

The measurement of TER across epithelial monolayers is used to evaluate the integrity of the cell monolayer (Srinivasan et al., 2015). The barrier function of IPEC-J2 cells was evaluated after the cells reached confluent state on 6-well membrane inserts. The results were calculated as $\mathrm{k} \Omega \times \mathrm{cm}^{2}$ by multiplying the values by the surface area of the insert $\left(4.67 \mathrm{~cm}^{2}\right)$.

TER measurements were carried out before treatment $(0 \mathrm{~h})$ to check the integrity values of the confluent, differentiated IPEC-J2 cells. Then TER was assessed after 24- and 25-h treatment of cells with DON, Que and their combination. TER values were measured using EVOM Epithelial Tissue Volt/Ohmmeter (World Precision Instruments, Berlin, Germany).

\section{Determination of extracellular $\mathrm{H}_{2} \mathrm{O}_{2}$ production}

The changes in $\mathrm{H}_{2} \mathrm{O}_{2}$ production were monitored in IPECJ2 cells with the Amplex Red Hydrogen Peroxide Assay Kit (Invitrogen, Molecular Probes, Carlsbad, CA, USA) (Zhao et al., 2012). In the presence of horseradish peroxidase, the Amplex Red reagent reacts with $\mathrm{H}_{2} \mathrm{O}_{2}$ (in 1:1 stoichiometry) to produce fluorescent resorufin.

After an incubation time of $25 \mathrm{~h}$ the cell-free supernatants of IPEC-J2 cells were taken. The tests were carried out according to the manufacturer's instructions. The fluorescence intensity was measured with a fluorometer using 560 $\mathrm{nm}$ excitation and $590 \mathrm{~nm}$ emission wavelengths (Victor X2 2030, Perkin Elmer, Waltham, MA, USA).

\section{Measurement of intracellular ROS in IPEC-J2 cells}

The measurement of alteration in intracellular redox state of IPEC-J2 cells was carried out using 2,7-dichlorodihydrofluorescein-diacetate (DCFH-DA) dye (Merck, Darmstadt, Germany) (Aranda et al., 2013). DCFH-DA is oxidised into the highly fluorescent form, dichlorofluorescein (DCF) by the intracellular ROS.

After a treatment time of $25 \mathrm{~h}$, the IPEC-J2 cells were taken and centrifuged at $1,000 \mathrm{rpm}$ for $10 \mathrm{~min}$ at $5{ }^{\circ} \mathrm{C}$. After that, the cell-free supernatant samples were collected. Fluorescence intensities of the supernatant were measured using $485 \mathrm{~nm}$ excitation and $530 \mathrm{~nm}$ emission wavelengths with a fluorometer (Victor X2 2030, Perkin Elmer, Waltham, MA, USA).

\section{Statistical analysis}

The statistical analysis of the results was performed by using the R Core Team (version of 2018). Differences between groups were analysed by one-way ANOVA coupled with the post-hoc Tukey's test for multiple comparisons. ${ }^{*} P<0.05$ and ${ }^{* * *} P<0.001$ were considered to be statistically significant.

\section{RESULTS}

\section{Cytotoxicity of DON and Que}

The effects of DON and Que on the viability of IPEC-J2 cells were evaluated after an incubation time of $24 \mathrm{~h}$ (Fig. 2). DON was applied in a concentration range of 0-50 $\mu \mathrm{mol} / \mathrm{L}$. DON caused significant cell death after $24 \mathrm{~h}$ of incubation at $50 \mu \mathrm{mol} / \mathrm{L}(P<0.001)$. The effect of Que was tested in a concentration range of $0-100 \mu \mathrm{mol} / \mathrm{L}$. Treatment with $75 \mu \mathrm{mol} / \mathrm{L}$ and higher concentrations of Que resulted in significant cell death rates compared to those in the controls after $24 \mathrm{~h}$. For further investigations non-cytotoxic concentrations of DON $(1 \mu \mathrm{mol} / \mathrm{L})$ and Que $(20 \mu \mathrm{mol} / \mathrm{L})$ were applied.

\section{Changes in transepithelial electrical resistance values after exposure to DON and Que}

To determine the effect of $1 \mu \mathrm{mol} / \mathrm{L} \mathrm{DON}$ and $20 \mu \mathrm{mol} / \mathrm{L}$ Que on the integrity of the IPEC-J2 cell monolayers, TER measurements were carried out (Fig. 3). After 24-h incubation and preincubation of the cells with $20 \mu \mathrm{mol} / \mathrm{L}$ Que, significant elevations in TER values compared to the control were found (Que: $P=0.0323 ; 24$-h pretreatment: $P=$ $0.0191)$. Exposure to $1 \mu \mathrm{mol} / \mathrm{L} \mathrm{DON}$ significantly reduced 

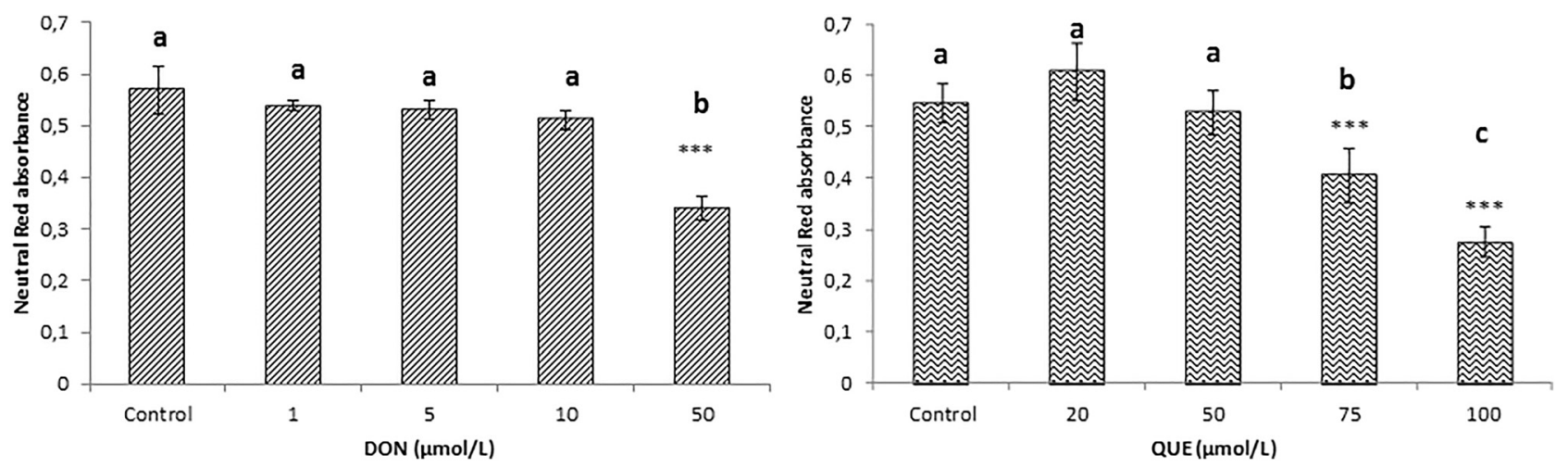

Fig. 2. Evaluation of the cytotoxicity of DON and Que on IPEC-J2 cells after an incubation time of 24 h. ${ }^{* * *} P<0.001$ compared to the control values. Data are presented as means \pm standard deviations (DONs: $n=5$; Que: $n=8$ ). Different letters show significant differences between control and DON-treated groups (DONs at $50 \mu \mathrm{mol} / \mathrm{L}$ ) and control and Que-treated groups (Que at 75 and $100 \mu \mathrm{mol} / \mathrm{L})(P<0.05)$

the TER values in IPEC-J2 cells $(P<0.001)$. Beneficial effects of the pretreatment and the co-treatment with $20 \mu \mathrm{mol} / \mathrm{L}$ Que were observed after $24 \mathrm{~h}$ and $25 \mathrm{~h}$, since significantly higher TER values were measured compared to those of cells treated only with DON.

\section{Evaluation of extracellular $\mathrm{H}_{2} \mathrm{O}_{2}$ production after DON and Que treatments}

After 25 -h treatment with $1 \mu \mathrm{mol} / \mathrm{L}$ DON, $20 \mu \mathrm{mol} / \mathrm{L}$ Que and their combination the extracellular $\mathrm{H}_{2} \mathrm{O}_{2}$ concentrations were measured (Fig. 4). Exposure to $20 \mu \mathrm{mol} / \mathrm{L}$ Que did not alter the $\mathrm{H}_{2} \mathrm{O}_{2}$ concentration in the cell-free supernatant $(P=0.4161)$. Also, the $24-\mathrm{h} 20 \mu \mathrm{mol} / \mathrm{L}$ Que $+1-\mathrm{h} 1 \mu \mathrm{mol} / \mathrm{L}$ DON treatment of the cells did not change the extracellular $\mathrm{H}_{2} \mathrm{O}_{2}$ production $(P=0.7006)$. Treatment with $1 \mu \mathrm{mol} / \mathrm{L}$ DON for $25 \mathrm{~h}$ caused a significant increase in extracellular $\mathrm{H}_{2} \mathrm{O}_{2}$ production $(P<0.001)$; furthermore, DON-exposed IPEC-J2 cells co-treated with $20 \mu \mathrm{mol} / \mathrm{L}$ Que for $1 \mathrm{~h}$ showed significantly elevated $\mathrm{H}_{2} \mathrm{O}_{2}$ production $(P=0.0003)$ compared to the control values. There were significant differences between the 1 -h $20 \mu \mathrm{mol} / \mathrm{L}$ Que $+1 \mu \mathrm{mol} / \mathrm{L} \mathrm{DON}$ and the $1 \mu \mathrm{mol} / \mathrm{L}$ DON treatments $(P=0.0072)$.

\section{Changes in intracellular ROS production after adding DON and Que to IPEC-J2 cells}

To estimate the changes in intracellular ROS production the DCFH-DA assay was used after 25-h incubation (Fig. 5). Treatment with $20 \mu \mathrm{mol} / \mathrm{L}$ Que did not change the fluorescence intensity values significantly $(P=0.9993)$. In the pretreated cells, DON administration significantly increased intracellular ROS production compared to the control and to Que-treated IPEC-J2 cells (both $P<0.001$ ). Exposure to $1 \mu \mathrm{mol} / \mathrm{L} \mathrm{DON}$ significantly enhanced the fluorescence intensities after 25 -h incubation $(P<0.001)$. After 1 -h co-treatment with $20 \mu \mathrm{mol} / \mathrm{L}$ Que and $1 \mu \mathrm{mol} / \mathrm{L}$ DON the fluorescence intensities of intracellular ROS were

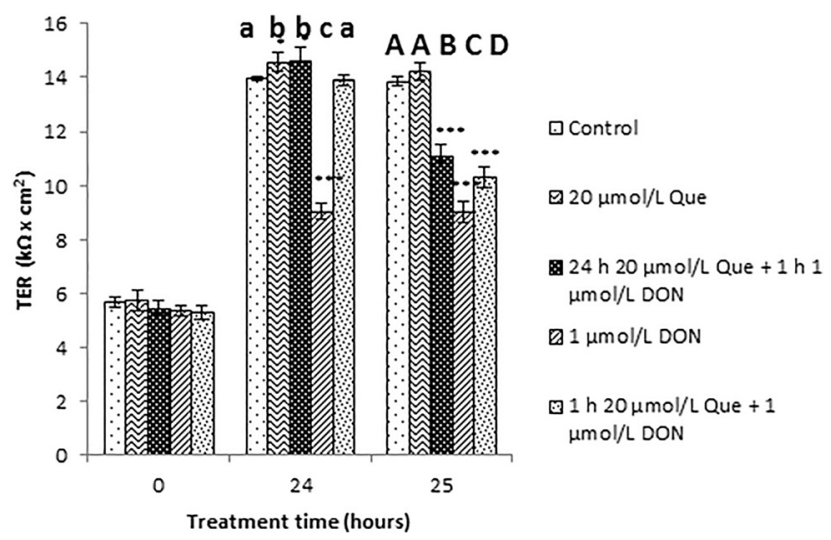

Fig. 3. The effects of DON and Que on the IPEC-J2 cell monolayer integrity. Prior to the experiments the TER values were measured $(0 \mathrm{~h})$. Cells were incubated with $1 \mu \mathrm{mol} / \mathrm{L} \mathrm{DON}, 20 \mu \mathrm{mol} / \mathrm{L}$ Que or the combination of these two compounds for 24 and $25 \mathrm{~h} .{ }^{* * *} P<$ 0.001 compared to the control values. Different small letters $(24 \mathrm{~h})$ and capital letters $(25 \mathrm{~h})$ show significant differences between the indicated groups. Data are presented as means \pm standard deviations $(n=6)$

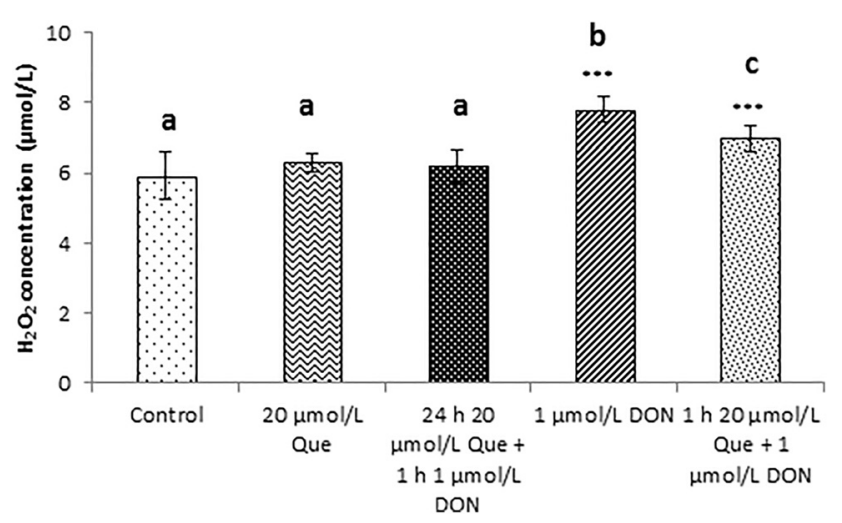

Fig. 4. The changes in $\mathrm{H}_{2} \mathrm{O}_{2}$ concentrations after DON and Que treatments. The results were obtained after $25 \mathrm{~h}$ incubation time, the IPEC-J2 cells were treated with $1 \mu \mathrm{mol} / \mathrm{L} \mathrm{DON,} 20 \mu \mathrm{mol} / \mathrm{L}$ Que or their combinations. ${ }^{* * *} P<0.001$ compared to the control values. Different letters show significant differences between the 24-h 20 $\mu \mathrm{mol} / \mathrm{L}$ Que $+1-\mathrm{h} 1 \mu \mathrm{mol} / \mathrm{L}$ DON- and $1 \mu \mathrm{mol} / \mathrm{L}$ DON-treated groups and between the control and the $1-\mathrm{h} 1 \mu \mathrm{mol} / \mathrm{L}$ DON-treated groups. Data are presented as means \pm standard deviations $(n=8)$ 


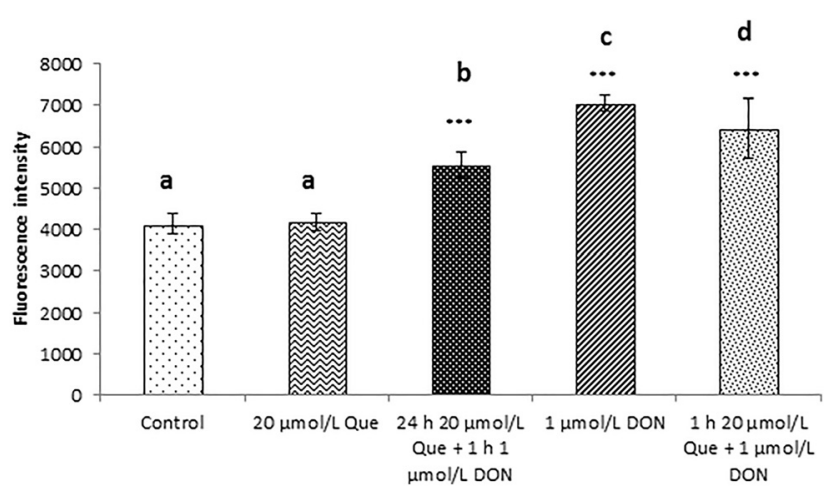

Fig. 5. The impact of DON and Que on the intracellular ROS levels in IPEC-J2 cells. Fluorescence intensities were measured in IPEC-J2 cells incubated with $1 \mu \mathrm{mol} / \mathrm{L} \mathrm{DON}, 20 \mu \mathrm{mol} / \mathrm{L}$ Que or their combinations after $25 \mathrm{~h}$. ${ }^{* * *} P<0.001$ compared to the control values. Different letters show significant differences between each indicated group. Data are presented as means \pm standard deviations $(n=8)$

significantly increased compared to the control values $(P=0.001)$. There were significant differences in intracellular redox status between the co-treatment and the treatment with $1 \mu \mathrm{mol} / \mathrm{L} \mathrm{DON}(\mathrm{b}, P=0.0315)$, and also between the pretreatment with $20 \mu \mathrm{mol} / \mathrm{L}$ Que and the $1 \mu \mathrm{mol} / \mathrm{L}$ DON treatment $(P<0.001)$.

\section{DISCUSSION}

DON, as a major contaminant of cereals, has been implicated in various gastrointestinal problems in farm animals, such as vomiting, feed refusal, diarrhoea (Pestka, 2008), oesophageal perforation as well as malabsorption (Awad et al., 2010). Therefore, it is essential to find naturally occurring feed additives to restore the mycotoxin-perturbed digestion of animals. It was indicated by Chen et al. (2018) that Que protects IPEC-J2 cells from oxidative damagemediated apoptosis and that the mechanism is related to the inhibition of the mitochondrial apoptosis pathway and lipid peroxidation. These findings indicate the effects of Que on proliferation enhancement of IPEC-J2 cells and their protection against $\mathrm{H}_{2} \mathrm{O}_{2}$-induced oxidative stress. The present study is the first research to investigate the potential protective ability of Que against DON-induced intestinal barrier dysfunction and oxidative stress in IPEC-J2 cells.

A great variety of cell viability assays can be used for evaluating the effect of foodborne compounds such as DON and the plant-derived Que. Vandenbroucke et al. (2011) reported that in the case of non-polarised IPEC-J2, cell death was significant upon 24-h addition of DON at concentrations as low as $0.8425-33.7 \mu \mathrm{mol} / \mathrm{L}$. A 24 -h treatment with Que at $16.5 \mu \mathrm{mol} / \mathrm{L}$ concentration resulted in significantly increased cell viability, while $33 \mu \mathrm{mol} / \mathrm{L}$ Que concentrations caused significant cell death in IPEC-J2 cells using the 3-(4,5dimethylthiazole-2-yl)-2,5-diphenyltetrazolium bromide (MTT) assay (Chen et al., 2018). Our results were similar to those found in that study as we found that Que was cytotoxic at concentrations of $75 \mu \mathrm{mol} / \mathrm{L}$ or higher. In contrast, using the NR assay Vergauwen et al. (2016) found that IPEC-J2 cells showed cell death only from $800 \mu \mathrm{mol} / \mathrm{L}$ concentration of Que for $18 \mathrm{~h}$. Yang et al. (2020) studied the effects of Que and DON on human, non-tumourigenic gastric epithelial cells (GES-1) and found that the treatment regimen involving 6.25 $\mu \mathrm{mol} / \mathrm{L}$ Que pretreatment for $2 \mathrm{~h}$ was suitable for further investigations according to the results of CCK8 cytotoxicity and lactate dehydrogenase $(\mathrm{LDH})$ release assays. Based on data of GES-1 cells which were pretreated with $6.25 \mu \mathrm{mol} / \mathrm{L}$ Que for $2 \mathrm{~h}$ followed by the administration of $5 \mu \mathrm{mol} / \mathrm{L} \mathrm{DON}$, it was confirmed that preincubation of the cells with 6.25 $\mu \mathrm{mol} / \mathrm{L}$ Que led to better cell viability values compared to those observed in cells treated with $5 \mu \mathrm{mol} / \mathrm{L} \mathrm{DON}$.

Polarised cells form strong barriers through the development of tight junctions between them. The TER of the epithelial cell monolayers was found to be a good indicator of the degree of epithelial integrity. Pinton et al. (2009) observed a dose-dependent decrease in TER values in differentiated IPEC-1 following treatment with $5 \mu \mathrm{mol} / \mathrm{L}$ DON after an incubation time of $24 \mathrm{~h}$. TER values were significantly reduced in IPEC-J2 cell monolayers after 24 -h exposure to basolaterally added DON at $6.74 \mu \mathrm{mol} / \mathrm{L}$ concentration (Diesing et al., 2011). Springler et al. (2016) reported that DON reduced TER significantly at 5-20 $\mu \mathrm{mol} / \mathrm{L}$ concentration after $24 \mathrm{~h}$. Our results are consistent with these findings, as TER significantly dropped after 24-h incubation with $1 \mu \mathrm{mol} / \mathrm{L}$ DON in polarised IPEC-J2 cells. Our co-treatment experiment also showed that $20 \mu \mathrm{mol} / \mathrm{L}$ Que was not able to prevent the harmful effects of DON.

Several publications have assessed the influence of Que on a Caco-2 cell line. Suzuki and Hara (2009) found that Que in a concentration range of $10-100 \mu \mathrm{mol} / \mathrm{L}$ significantly increased TER after an incubation time of 24 and $48 \mathrm{~h}$. Amasheh et al. (2008) reported that $200 \mu \mathrm{mol} / \mathrm{L}$ of Que was the most effective concentration in improving TER in Caco2 cells after $24 \mathrm{~h}$. Vergauwen et al. (2016) concluded that the preincubation of IPEC-J2 cells with 25-200 $\mu \mathrm{mol} / \mathrm{L}$ Que for $18 \mathrm{~h}$ could strengthen the integrity of the cell monolayer. In our experiments, IPEC-J2 cells were pretreated with 20 $\mu \mathrm{mol} / \mathrm{L}$ Que for $24 \mathrm{~h}$ and the TERs of cell monolayers were increased significantly. Carrasco-Pozo et al. (2013) observed that $33 \mu \mathrm{mol} / \mathrm{L}$ Que significantly elevated the TER values in Caco- 2 cells when the non-steroidal anti-inflammatory drug indomethacin was given at a concentration of $250 \mu \mathrm{mol} / \mathrm{L}$. Our results are in good correlation with these findings, as the TER values of cells co-treated and pretreated with $20 \mu \mathrm{mol} / \mathrm{L}$ Que were significantly higher than those measured in cells treated with $1 \mu \mathrm{mol} / \mathrm{L} \mathrm{DON}$ after an incubation time of $25 \mathrm{~h}$.

In the literature, there are only few publications in connection with the extracellular $\mathrm{H}_{2} \mathrm{O}_{2}$ production in IPECJ2 cells. As Pászti-Gere et al. (2015) reported, IPEC-J2 cells are appropriate model systems to study the effects of different molecules on the redox status of cells. In our experiments it was found that extracellular $\mathrm{H}_{2} \mathrm{O}_{2}$ production was significantly elevated after 25 -h treatment with $1 \mu \mathrm{mol} / \mathrm{L}$ DON. Pretreatment with $20 \mu \mathrm{mol} / \mathrm{L}$ Que followed by 
exposure to $1 \mu \mathrm{mol} / \mathrm{L}$ DON for $1 \mathrm{~h}$ did not show significant changes in $\mathrm{H}_{2} \mathrm{O}_{2}$ production compared to control values. Co-treatment with $20 \mu \mathrm{mol} / \mathrm{L}$ Que and $1 \mu \mathrm{mol} / \mathrm{L} \mathrm{DON}$ for $1 \mathrm{~h}$ significantly increased the $\mathrm{H}_{2} \mathrm{O}_{2}$ concentration. According to these findings, the pretreatment has a potential to prevent DON-induced extracellular $\mathrm{H}_{2} \mathrm{O}_{2}$ production, while a 1-h-long treatment with Que was not able to hinder the effect of DON-induced $\mathrm{H}_{2} \mathrm{O}_{2}$ overproduction.

Kang et al. (2019) reported that DON at a concentration of $6.7 \mu \mathrm{mol} / \mathrm{L}$ significantly elevated intracellular ROS levels in IPEC-J2 cells after 24-h mycotoxin exposure, as measured by the DCFH-DA assay. Vergauwen et al. (2016) carried out experiments on IPEC-J2 cells with 5-(and-6-)-chloromethyl20,70-dichlorodihydrofluorescein diacetate acetyl ester (CM$\mathrm{H}_{2}$ DCFDA) using various concentrations of Que, and confirmed that Que could reduce intracellular ROS. Using the DCFH-DA assay, Chen et al. (2018) demonstrated that the ROS content in IPEC-J2 cells was reduced dramatically by Que at $16.5 \mu \mathrm{mol} / \mathrm{L}$ concentration. In our study, $1 \mu \mathrm{mol} / \mathrm{L}$ DON significantly increased the intracellular ROS content. The cells treated with $20 \mu \mathrm{mol} / \mathrm{L}$ Que did not show differences compared to the control cells. While the Que-pretreated cells exposed to DON showed a significant increase in fluorescence intensity, these values were significantly lower compared to those of cells treated with DON only.

In conclusion, Que at a concentration of $20 \mu \mathrm{mol} / \mathrm{L}$ supports the cell monolayer to maintain optimal intestinal epithelial barrier integrity. It was also observed that pretreatment with Que displays a favourable effect against the DON-induced oxidative imbalance. In contrast, the simultaneous, short (1-h long) treatment with Que did not contribute to the restoration of the tipped redox homoeostasis induced by DON administration.

\section{ACKNOWLEDGEMENTS}

This research was supported by the Hungarian Scientific Research Fund (grant numbers 115685 and 124522). The work was supported by the European Union and cofinanced by the European Social Fund (grant agreement no. EFOP-3.6.1-16-2016-00024, EFOP-3.6.2-16-2017-00012 and EFOP-3.6.3-VEKOP-16-2017-00005). The project received support from the János Bolyai Research Scholarship of the Hungarian Academy of Sciences. We would like to express special thanks to Júlia Seprődi for the chemical background and to Ágnes Eszter Czimmermann and Réka Fanni Barna for their technical support.

\section{REFERENCES}

AbdulSalam, S. F., Thowfeik, F. S. and Merino, E. J. (2016): Excessive reactive oxygen species and exotic DNA lesions as an exploitable liability. Biochemistry 55, 5341-5352.

Abotaleb, M., Samuel, S. M., Varghese, E., Varghese, S., Kubatka, P., Liskova, A. and Büsselberg, D. (2018): Flavonoids in cancer and apoptosis. Cancers 11, 28.
Amasheh, M., Schlichter, S., Amasheh, S., Mankertz, J., Zeitz, M., Fromm, M., and Schulzke, J. D. (2008): Quercetin enhances epithelial barrier function and increases claudin-4 expression in Caco-2 cells. J. Nutr. 138, 1067-1073.

Aranda, A., Sequedo, L., Tolosa, L., Quintas, G., Burello, E., Castell, J. V. and Gombau, L. (2013): Dichloro-dihydro-fluorescein diacetate (DCFH-DA) assay: a quantitative method for oxidative stress assessment of nanoparticle-treated cells. Toxicol. In Vitro 27, 954-963.

Awad, W. A., Ghareeb, K., Bohm, J. and Zentek, J. (2010): Decontamination and detoxification strategies for the Fusarium mycotoxin deoxynivalenol in animal feed and the effectiveness of microbial biodegradation. Food Addit. Contam. Part A Chem. Anal. Control Expo. Risk Assess. 27, 510-520.

Brunetti, C., Di Ferdinando, M., Fini, A., Pollastri, S. and Tattini, M. (2013): Flavonoids as antioxidants and developmental regulators: relative significance in plants and humans. Int. J. Mol. Sci. 14, 3540-3555.

Carrasco-Pozo, C., Morales, P. and Gotteland, M. (2013): Polyphenols protect the epithelial barrier function of Caco-2 cells exposed to indomethacin through the modulation of occludin and zonula occludens-1 expression. J. Agric. Food Chem. 61, 5291-5297.

Chahar, M. K., Sharma, N., Dobhal, M. P. and Joshi, Y. C. (2011): Flavonoids: a versatile source of anticancer drugs. Phcog. Rev. 5, 1-12.

Chen, Z., Yuan, Q., Xu, G., Chen, H., Lei, H. and Su, J. (2018): Effects of quercetin on proliferation and $\mathrm{H}_{2} \mathrm{O}_{2}$-induced apoptosis of intestinal porcine enterocyte cells. Molecules 12, E2012.

D'Andrea, G. (2015): Quercetin: a flavonol with multifaceted therapeutic applications? Fitoterapia 106, 256-271.

Diekman, M. A. and Green, M. L. (1992): Mycotoxins and reproduction in domestic livestock. J. Anim. Sci. 70, 1615-1627.

Diesing, A. K., Nossol, C., Dänicke, S., Walk, N., Post, A., Kahlert, S., Rothkötter, H. J. and Kluess, J. (2011): Vulnerability of polarised intestinal porcine epithelial cells to mycotoxin deoxynivalenol depends on the route of application. PLoS One 6, e17472.

Galleano, M., Verstraeten, S. V., Oteiza, P. I. and Fraga, C. G. (2010): Antioxidant actions of flavonoids: thermodynamic and kinetic analysis. Arch. Biochem. Biophys. 501, 23-30.

Goossens, J., Pasmans, F., Verbrugghe, E., Vandenbroucke, V., De Baere, S., Meyer, E., Haesebrouck, F., De Backer, P. and Croubels, S. (2012): Porcine intestinal epithelial barrier disruption by the Fusarium mycotoxins deoxynivalenol and T-2 toxin promotes transepithelial passage of doxycycline and paromomycin. BMC Vet. Res. 8, 245.

Holladay, S. D., Blaylock, B. L., Comment, C. E., Heindel, J. J. and Luster, M. I. (1993): Fetal thymic atrophy after exposure to T-2 toxin: selectivity for lymphoid progenitor cells. Toxicol. Appl. Pharmacol. 121, 8-14.

Kang, R., Li, R., Dai, P., Li, Z., Li, Y. and Li, C. (2019): Deoxynivalenol induced apoptosis and inflammation of IPEC-J2 cells by promoting ROS production. Environ. Pollut. 251, 689-698.

Kroon, P. A., Clifford, M. N., Crozier, A., Day, A. J., Donovan, J. L. and Manach, C. (2004): How should we assess the effects of exposure to dietary polyphenols in vitro. Am. J. Clin. Nutr. 80, 15-21. 
Kumar, S. and Pandey, A. K. (2013): Chemistry and biological activities of flavonoids: an overview. Sci. World J. 162750.

Li, Y., Wang, Z., Beier, R. C., Shen, J., De Smet, D., De Saeger, S. and Zhang, S. (2011): T-2 toxin, a trichothecene mycotoxin: review of toxicity, metabolism, and analytical methods. J. Agric. Food Chem. 59, 3441-3453.

Paszti-Gere, E., Csibrik-Nemeth, E., Szeker, K., Csizinszky, R., Jakab, C. and Galfi, P. (2012a): Acute oxidative stress affects IL8 and TNF- $\alpha$ expression in IPEC-J2 porcine epithelial cells. Inflammation 35, 994-1004.

Paszti-Gere, E., Szeker, K., Csibrik-Nemeth, E., Csizinszky, R., Marosi, A., Palocz, O., Farkas, O. and Galfi, P. (2012b): Metabolites of Lactobacillus plantarum 2142 prevent oxidative stress-induced overexpression of proinflammatory cytokines in IPEC-J2 cell line. Inflammation 35, 1487-1499.

Pászti-Gere, E., McManus, S., Meggyesházi, N., Balla, P., Gálfi, P. and Steinmetzer, T. (2015): Inhibition of matriptase activity results in decreased intestinal epithelial monolayer integrity in vitro. PloS One 10, e0141077.

Pestka, J. J. (2008): Mechanisms of deoxynivalenol-induced gene expression and apoptosis. Food Addit. Contam. 25, 1128-1140.

Pinton, P., Nougayrede, J. P., Del Rio, J. C., Moreno, C., Marin, D. E., Ferrier, L., Bracarense, A. P., Kolf-Clauw, M. and Oswald, I. P. (2009): The food contaminant deoxynivalenol, decreases intestinal barrier permeability and reduces claudin expression. Toxicol. Appl. Pharmacol. 237, 41-48.

Placinta, C. M., Mello, J. P. F. and Macdonald, A. M. C. (1999): A review of worldwide contamination of cereal grains and animal feed with Fusarium mycotoxins. Anim. Feed Sci. Technol. 78, 21-37.

R Core Team (2018): R: A Language and Environment for Statistical Computing. R Foundation for Statistical Computing, Vienna, Austria. Available online at https://www.R-project.org/.

Repetto, G., del Peso, A. and Zurita, J. L. (2008): Neutral red uptake assay for the estimation of cell viability/cytotoxicity. Nat. Protoc. 3, 1125-1131.

Ružić, I., Škerget, M. and Knez, Ž. (2010): Potential of phenolic antioxidants. Acta Chim. Slov. 57, 263-271.

Sak, K. (2014): Dependence of DPPH radical scavenging activity of dietary flavonoid quercetin on reaction environment. Mini Rev. Med. Chem. 14, 494-504.

Serafini, M., Peluso, I., and Raguzzini, A. (2010): Flavonoids as antiinflammatory agents. Proc. Nutr. Soc. 69, 273-278.

Springler, A., Hessenberger, S., Schatzmayr, G. and Mayer, E. (2016): Early activation of MAPK p44/42 is partially involved in DON-induced disruption of the intestinal barrier function and tight junction network. Toxins 8, 264.
Srinivasan, B., Kolli, A. R., Esch, M. B., Abaci, H. E., Shuler, M. L. and Hickman, J. J. (2015): TEER measurement techniques for in vitro barrier model systems. J. Lab. Autom. 20, 107-126.

Su, L. J., Zhang, J. H., Gomez, H., Murugan, R., Hong, X., Xu, D., Jiang, F. and Peng, Z. Y. (2019): Reactive oxygen speciesinduced lipid peroxidation in apoptosis, autophagy, and ferroptosis. Oxid. Med. Cell. Longev. 2019, 5080843.

Sundheim, L., Brodal, G., Hofgaard, I. S. and Rafoss, T. (2013): Temporal variation of mycotoxin producing fungi in Norwegian cereals. Microorganisms 1, 188-198.

Suzuki, T. and Hara, H. (2009): Quercetin enhances intestinal barrier function through the assembly of zonula occludens-2, occludin, and claudin-1 and the expression of claudin- 4 in Caco-2 cells. J. Nutr. 139, 965-974.

Vandenbroucke, V., Croubels, S., Martel, A., Verbrugghe, E., Goossens, J., Van Deun, K., Boyen, F., Thompson, A., Shearer, N., De Backer, P., Haesebrouck, F. and Pasmans, F. (2011): The mycotoxin deoxynivalenol potentiates intestinal inflammation by Salmonella Typhimurium in porcine ileal loops. PLoS One 6, e23871.

Vergauwen, H., Prims, S., Degroote, J., Wang, W., Casteleyn, C., van Cruchten, S., de Smet, S., Michiels, J. and van Ginneken, C. (2016): In vitro investigation of six antioxidants for pig diets. Antioxidants (Basel) 5, 41.

Wan, M. L. Y., Turner, P. C., Co, V. A., Wang, M. F., Amiri, K. M. A. and El-Nezami, H. (2019): Schisandrin A protects intestinal epithelial cells from deoxynivalenol-induced cytotoxicity, oxidative damage and inflammation. Sci. Rep. 9, 19173.

Xie, Y., Yang, W., Tang, F., Chen, X. and Ren, L. (2015): Antibacterial activities of flavonoids: structure-activity relationship and mechanism. Curr. Med. Chem. 22, 132-149.

Yang, Y. X., Yu, S., Jia, B. X., Liu, N. and Wu, A. (2020): Metabolomic profiling reveals similar cytotoxic effects and protective functions of quercetin during deoxynivalenol- and 15-acetyl deoxynivalenol-induced cell apoptosis. Toxicol. In Vitro 66, 104838.

Zakrzewski, S. S., Richter, J. F., Krug, S. M., Jebautzke, B., Lee, I. F., Rieger, J., Sachtleben, M., Bondzio, A., Schulzke, J. D., Fromm, M. and Günzel, D. (2013): Improved cell line IPEC-J2, characterized as a model for porcine jejunal epithelium. PLoS One 8, e79643.

Zhao, B., Summers, F. A. and Mason, R. P. (2012): Photooxidation of Amplex Red to resorufin: implications of exposing the Amplex Red assay to light. Free Radic. Biol. Med. 53, 10801087.

Open Access. This is an open-access article distributed under the terms of the Creative Commons Attribution 4.0 International License (https://creativecommons.org/ licenses/by/4.0/), which permits unrestricted use, distribution, and reproduction in any medium, provided the original author and source are credited, a link to the CC License is provided, and changes - if any - are indicated. (SID_1) 